\title{
ANALISIS WACANA KRITIS SARA MILLS \\ DALAM NOVEL BERKISAR MERAH KARYA AHMAD TOHARI
}

\author{
Mella Andriana ${ }^{1}$, Ngusman Abdul Manaf ${ }^{2}$ \\ 1,2Program Studi Pendidikan Bahasa dan Sastra Indonesia, \\ Fakultas Bahasa dan Seni, Universitas Negeri Padang \\ ${ }^{1}$ mellaandriana87@gmail.com
}

\begin{abstract}
Abstrak
Tujuan penelitian ini ialah untuk menganalisis dan mendeskripsikan wacana kritis dalam novel Berkisar Merah karya Ahmad Tohari dengan Pendekaran Sara Mills. Jenis penelitian ini adalah penelitian kualitatif dengan menggunakan metode deskriptif. Data penelitian ini berupa feminisme yaitu teks yang menggambarkan bagaimana perempuan ditampilkan dalam novel Berkisar Merah Karya Ahmad Tohari. Sumber data penelitian ini adalah teks novel Berkisar Merah Karya Ahmad Tohari. Teknik pengumpulan data yang peneliti gunakan dalam penelitian ini adalah membaca keseluruhan novel secara berulang- ulang, kemudian mencatat hal - hal yang berkaitan dengan objek penelitian. Teknik pencatatan yang digunakan adalah teknik pencatatan selektif. Teknik pencatatan selektif digunakan untuk mencatat data dari sumber data yang sesuai dengan kriteria yang telah ditentukan. Kriteria yang dimaksud adalah penggalan teks atau dialog tokoh maupun antartokoh dalam novel yang diduga menampilkan suatu permasalahan yang menunjukkan bagaimana perempuan ditampilkan dalam teks. Hasil dari penelitian ini ditemukan posisi subjek 4 data, posisi objek 3 data, dan posisi pembaca 4 data.
\end{abstract}

Kata Kunci: Wacana Kritis, Sara Mills, Novel Berkisar Merah

\begin{abstract}
The purpose of this study is to analyze and describe the critical discourse in the novel Berkisar Merah by Ahmad Tohari with Approach by Sara Mills. This type of research is qualitative research using descriptive method. The data of this research is in the form of feminism, which is a text that describes how women are presented in the novel "Berkisar Merah by Ahmad Tohari". The data source of this research is the text of the novel Berkisar Merah by Ahmad Tohari. The data collection technique that the researcher used in this research was to read the entire novel repeatedly, then take notes on matters related to the research object. The recording technique used is the iselective recording technique. Selective recording technique is used to record data from data sources that are in accordance with predetermined criteria. The criteria in question are fragments of text or dialogue between characters and between characters in the novel which are suspected of presenting a problem which shows how women are represented in the text. The results of this study found the position of the subject with 4 data, the position of the object with 3 data, and the position of the reader with 4 data.
\end{abstract}

Keywords: Critical Discourse, Sara Mills, Novel Berkisar Merah

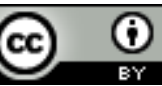

Creative Commons Attribution 4.0 International (CC BY 4.0) 


\section{PENDAHULUAN}

Karya sastra merupakan sebuah teks yang ditulis berdasarkan pengalaman yang dirasakan oleh pengarang yang dituangkan di dalam bentuk tulisan yang memiliki makna denotatif. Adanya karya sastra mempermudah pembaca ataupun peneliti untuk mendapatkan objek kajian yang ingin diteliti karena pada saat ini sudah banyak ditemukan penelitian mengenai sebuah karya sastra seperti novel, puisi, cerpen, dan sebagainya.

Karya sastra yang menggambarkan perjalanan hidup seseorang, budaya, politik, dan sebagainya disebut dengan novel. Tentu saja novel-vovel karya sastrawan menjadi daya tarik tersendiri bagi pembaca, tergantung bagaimana penilaian pembaca terhadap novel yang dibaca. Hal ini dikarenakan setiap individu tentu saja mempunyai selera yang berbeda-beda disetiap karya sastra yang dibacanya. Tidak bisa kita pungkiri bahwa di dalam novel akan ditemukan masalah gender. Gender yang dimaksud adalah bagaimana pandangan ataupun penilaian terhadap laki-laki dan perempuan dalam pembentukan perilaku bermasyarakat. Sering kita temui bahwa di dalam kehidupan sehari-hari wanita dianggap lemah, tertindas, tidak berdaya dan sebagainya.

Novel yang berjudul Berkisar Merah karya Ahmad Tohari dipilih untuk dijadikan objek penelitian dari sekian banyak karya sastra yang memberikan gambaran tentang bagaiman ketidakadilan pengaruh perbedaan gender yang dialami oleh tokoh utama berdasarkan analisis wacana kritis oleh Sara Mills. Novel Bekisar Merah karya Ahmad Tohari mengangkat cerita kehidupan yang sangat nyata. Pengarang pun menggambarkan suasana yang masih alami dari Desa Karangsoga yang sangat indah dan juga menggambarkan nilai-nilai sosial yang sangat sulit dipahami oleh seorang perempuan desa yang sederhana dengan tingkat pendidikan yang rendah.

Kajian wacana pada umumnya digunakan untuk menganalisis suatu teks untuk memahami pesan yang terkandung. Renkema (2004) mendenisikan Kajian Wacana sebagai disiplin ilmu yang mempelajari hubungan antara bentuk dan fungsi dalam bentuk komunikasi verbal (baik lisan maupun tulisan). Tujuan dari Kajian Wacana adalah memberikan penjelasan dari hubungan yang berbelit- belit antara unsur-unsur wacana dan fungsinya dalam komunikasi. Analisis wacana dipandang kritis atau dikenal dengan analisis wacana kritis karena menekankan konstelasi kekuatan yang terjadi pada proses produksi dan reproduksi makna. Individu dipandang tidak sebagai subjek yang netral yang menafsirkan secara bebas sesuai dengan pikirannya karena sangat dipengaruhi dan berhubungan oleh kekuatan sosial yang ada dalam masyarakat (Eriyanto, 2002). Fairclough (2003) memandang analisis wacana kritis sebagai penyatuan analisis teks, analisis proses produksi, distribusi dan konsumsi teks serta analisis sosiokultural dari praktik diskursif.

Wacana merupakan unsur bahasa yang bersifat pragmatis. Apalagi pemakaian dan pemahaman pada tataran wacana dalam komunikasi memerlukan berbagai alat (piranti) yang cukup banyak. Oleh sebab itu, kajian mengenai wacana menjadi wajib ada dalam proses pembelajaran bahasa tujuannya ialah membekali pemakai bahasa agar dapat memahami dan menggunakan bahasa secara baik dan benar. Ghufron (2015) menjelaskan bahwa wacana merupakan sebuah karangan yang utuh. Keutuhan inilah yang membuat penutur dan mitra tutur saling memahami satu sama lain.

Analisis wacana kritis didefinikan sebagai upaya untuk menjelaskan suatu teks pada fenemona sosial untuk mengetahui kepentingan yang termuat di dalamnya. Wacana sebagai bentuk praktis sosial dapat dianalisis dengan analisis wacana kritis untuk mengetahui hubungan antara wacana dan perkembangan sosial budaya dalam domain 
sosial yang berbeda dalam dimensi linguistik. Analisis wacana krirtis berperan penting dalam kehidupan sosial masyarakat sebagai upaya menjelaskan fenomena sosial dan kepentingan termuat dalam suatu teks. Analisis wacana merupakan analisis unit linguistik terhadap penggunaan bahasa lisan maupun tulis yang melibatkan penyampai pesan dengan penerima pesan dalam tindak komunikasi.

Perkembangan analisis wacana kritis oleh para ahli telah melahirkan beragam teori dengan pendekatan. Dalam perkembangannya, analisis wacana membantu memahami bahasa dalam penggunaannya. Bahasa bukan hanya sekadar menjadi alat komunikasi, tetapi juga digunakan sebagai alat dalam menerapkan strategi kekuasaan. Kemampuan memahami fungsi bahasa dapat meningkatkan efektivitas komunikasi dan strategi wacana. Berbagai cara untuk mendeskripsikan realitas atau muatan dalam bahasa yang menyiratkan adanya kepentingan, maksud dan tujuan tertentu, membutuhkan ketajaman dalam penafsiran.

Sara Mills menulis mengenai teori wacana terutama wacana seputar feminisme sehingga yang dikemukakan oleh Sara Mills disebut sebagai persepektif feminis. Titik perhatian dari persepektif wacana feminis adalah menunjukan bagaimana teks bias dalam menampilkan wanita. Gagasan dari Sara Mills (1992) sedikit berbeda dengan model critical linguistic seperti yang diuraikan pada bagian terdahulu. Crirical linguistic hanya memusatkan perhatian pada struktur kebahasaan dan bagaimana pengaruhnya dalam pemaknaan khalayak. Sara Mills (dalam Eriyanto, 2006) lebih melihat pada bagaimana peran pelaku ditampilkan dalam teks dan peran pembaca serta penulis ditampilkan dalam teks. Pada akhirnya gaya pemaparan dan peran yang ditempatkan dan ditampilkan dalam teks ini akan membentuk pihak yang legitimate dan illegitimate yaitu pihak yang berkuasa dan menjadi pihak minoritas yang dikendalikan.

Masitoh (2020) menyatakan bahwa pendekatan analisis wacana kritis Sara Mills memfokuskan seperti apa perempuan dimunculkan dalam wacana. Selama ini perempuan selalu disingkirkan dan berada dalam keadaan yang tidak baik dan para perempuan itu tidak diberikan kesempatan untuk membela diri. Pendekatan wacana kritis ini sering disebut sebagai pendekatan analisis wacana perspektif feminis/feminist stylistics. Sara Mills mengembangkan analisis untuk melihat bagaimana posisi-posisi aktor ditampilkan dalam teks. Dalam arti siapa yang menjadi subjek penceritaan dan siapa yang menjadi objek penceritaan. Dengan demikian, akan didapatkan bagaimana struktur teks dan bagaimana makna diperlakukan dalam teks secara keseluruhan. Sara Mills juga melihat bagaimana pembaca dan penulis diperlakukan dalam teks. Bagaimana pembaca mengidentifikasi dan menempatkan dirinya dalam penceritaan teks. Posisi semacam ini akan menempatkan pembaca pada salah satu posisi dan mempengaruhi bagaimana teks itu ditampilkan. Pada akhirnya cara penceritaan dan posisi-posisi yang ditempatkan dan ditampilkan dalam teks ini membuat satu pihak menjadi terlegitimasi dan pihak lain menjadi tak terlegitimasi (Fauzan, 2014).

Beberapa penelitian yang juga membahas analisis wacana kritis Sara Miils pertama, penelitian yang dilakukan oleh Dini Permata Sari pada tahun (2012) dengan judul "Komodifikasi Perempuan dalam Iklan (Analisis Wacana Kritis Sara Mills pada Iklan Purbasari Lulur Mandi)". Kedua, penelitian yang dilakukan oleh Dwi Viora (2018) dengan judul Gender dan Feminisme dalam Surat Kabar Harian Pekanbaru Metro Espres (MX): Kajian Analisis Wacana Kritis Perspektif Sara Mills. Ketiga, oleh Ummamah Nisa Uljannah (2017) yang berjudul "Gerakan Perlawanan Perempuan dalam Novel Maryam Karya Okky Madasari dengan Pendekatan Sara Mills”. 
Dari ketiga penelitian yang sudah dijabarkan di atas, dapat diambil kesimpulan bahwa terdapat perbedaan dan persamaan yang ada antara penelitian ini dan penelitian tersebut. Persamaannya sama-sama menganalisis wacana kritis dengan menggunakan pendekatan Sara Mills, namun dengan objek yang berbeda.

Berdasarkan pemaparan di atas, untuk menegaskan alasan penelitian ini penting untuk dilakukan ialah karena penelitian sejenis belum banyak ditemukan. Maksudnya, fokus perhatian pada penelitian ini yaitu wacana feminisme, bagaimana perempuan ditampilkan dalam teks. Perempuan cenderung ditampilkan dalam teks sebagai pihak yang lemah, marjinal dibanding dengan pihak laki-laki. Ketidakadilan dan penggambaran yang buruk mengenai perempuan inilah yang menjadi sasaran utama penelitian ini. Maka dari itu perlu dilakukan penelitian tentang analisis wacana kritis Sara Mills dalam novel Berkisas Merah karya Ahmad Tohari.

\section{METODE PENELITIAN}

Metode penelitian yang digunakan dalam penelitian ini adalah metode kualitatif deskriptif. Seperti yang dikemukakan Moleong (2004) penelitian kualitatif memiliki karakteristik sebagai berikut. Pertama, latar alamiah. Kedua, manusia sebagai instrumen. Ketiga, penelitian kualitatif bersifat deskriptif. Keempat, analisis data secara induktif. Kelima, lebih mementingkan proses dari pada hasil. Data penelitian ini adalah feminisme, bagaimana perempuan ditampilkan dalam novel Berkisar Merah karya Ahmad Tohari.

Sumber data penelitian ini adalah teks novel Berkisar Merah karya Ahmad Tohari. Teknik pengumpulan data yang digunakan adalah membaca keseluruhan novel secara berulang-ulang, kemudian mencatat hal-hal yang berkaitan dengan objek penelitian. Teknik pencatatan yang digunakan adalah teknik pencatatan selektif. Teknik pencatatan selektif digunakan untuk mencatat data dari sumber data yang sesuai dengan kriteria yang telah ditentukan. Kriteria yang dimaksud adalah penggalan teks atau dialog tokoh maupun antartokoh dalam novel yang diduga menampilkan suatu permasalahan yang menunjukkan bagaimana perempuan ditampilkan dalam teks.

\section{HASIL DAN PEMBAHASAN}

Sara Mills (dalam Eriyanto, 2002) dengan menggunakan analisis Althusser lebih mengutamakan peran pelaku pada teks. Peran ini dikatakan sebagai bentuk memposisikan seseorang yaitu sebagai penafsir dan posisi yang ditafsirkan menekankan bagaimana aktor diposisikan dalam teks. Oleh karena itu, ada dua hal yang harus diutamakan, yaitu bagaimana pelaku dalam teks tersebut diposisikan dan bagaimana pelaku sebagai penafsir atau yang ditafsirkan dalam pemberitaan. Peran pelaku dalam teks baik sebagi penafsir maupun yang ditafsirkan yaitu untuk memaknai terjadinya peristiwa seperti apa dan bagaimana. Bahkan akan berdampak pada bagaimana peran pembaca dalam teks yang merupakan hasil negosiasi antara pembaca dan penulis. Hal ini merupakan gambaran bahwa pembaca digambarkan oleh penulis sesuai dengan imajinasi penulis.

\section{Posisi Subjek -Objek}

Jika dilihat dari objek penelitian ini, metode penelitian Analisis Wacana Kritis (AWK) Feminisme Sara Mills bermaksud menentukan siapakah yang menjadi subjek maupun objek di dalam novel Berkisar Merah karya Ahmad Tohari yang mana menggambarkan kedua posisi tersebut dari sang pengarang sebagai sudut pandang utama dari pihak ketiga dan sang tokoh utama perempuan di dalam novel tersebut. Keberadaan pengarang sebagai pencerita merupakan sudut pandang dalam novel ini di mana ia yang 
memegang kendali atas berjalannya cerita. Oleh sebab itu, representasi perempuan yang dibentuk dalam novel ini akan sangat terpengaruh oleh sang pengarang dalam menceritakan serangkaian peristiwa yang ada dalam novel ini dalam kerangka ideologi yang diusungnya, sedangkan untuk posisi objek, sang tokoh perempuan yang menjadi tokoh utama di dalam novel ini menjelaskan keberadaannya yang mendapatkan perlakukan tidak adil di dalam masyarrakat, terjadinya ketidakadilan yang ia terima di dalam hidupnya.

\section{Posisi Subjek}

Seperti yang dijelaskan sebelumnya, posisi subjek disini merupakan sang penulis sebagai sudut pandang pencerita jalannya kejadian. Adapun kutipannya sebagai berikut:

"Lasi merasa sakit bila mengingat dirinya sudah bekerja keras disbanding penjual lainnya namun Lasi selalu dipandang sebelah mata karena satatusnya sebagai perempuan yang dianggap tidak pantas melakukan pekerjaan tersebut (Berkisar Merah, 1993:206)”.

Dari kutipan tersebut, terlihat bahwa penulis menggambarkan ketidakadilan atau terjadinya marginalisasi terhadap tokoh perempuan di dalam novel tersebut, yaitu Lasi. Tokoh Lasi digambarkan oleh penulis, yaitu hanya dipandang sebelah mata oleh masyarakat dalam bekerja karena Lasi seorang perempuan. Kutipan di atas terlihat bahwa perempuan tidak mempunyai wewenang dan tidak berhak bekerja layaknya seorang lakilaki, masyarakat hanya menganggap perempuan sebagai makhluk yang lemah dan jauh di bawah laki-laki sehingga laki-laki sesenaknya saja bersikap terhapat perempuan yaitu Lasi.

"Lasi selesai mandi. Rambutnya basah tergerai, terjun ke belakang telinga kanan, melintir ke depan dan terjumpai di dada. Para pemuda desa ingin melampiaskan nafsunya kepada Lasi dengan menggoda Lasi. Dan Lasi mencabut kayu penggaris dari ketiaknya, lari menyebrang titian dan siap melampiaskan kemarahan kepada para penggoda tersebut (Bekisar Merah, 1993:25)”.

Pada kutipan di atas sang pengarang mencoba menjelaskan kepada pembaca bahwa Lasi mendapat perlakuan yang tidak baik dari pemuda desa. Pengarang menggambarkan konteks tuturan di atas terjadi ketika Lasi selesai mandi di sungai dan para pemuda desa ingin melampiaskan nafsunya kepada Lasi karena tergoda akan kecantikan Lasi. Pada kutipan tersebut perempuan sebagai korban yang selalu dianggap lemah dibanding lakaki-laki dan Lasi sebagai tokoh perempuan mendapatkan perlakuan yang tidak senonoh dari para laki-laki. Kutipan di atas terjadi ketidakadilan terhadap perempuan yang dialami oleh Lasi. Perempuan hanya dianggap wanita yang lemah sehingga laki-laki dengan mudahnya melakukan hal yang tidak senonoh seperti yang dialami oleh Lasi pada kutipan di atas. Lasi hampir diperkosa oleh para lelaki karena mereka lebih kuat dari segi fisik dan wanita dijadikan sebagai pelampiasannya.

"Lasi selalu mendapat perlakuan yang tidak baik dari masyarakat sekitar karena ia keturunan Jepang dan anak hasil pemerkosaan. Lasi selalu disebut sebagai anak haram, bahkan keluarganyapun tidak membela Lasi ketika Lasi mendapat perlakukan yang tidak sepantasnya. Ayah Darsa selalu menyuruh Darsa untuk menceraikan Lasi dan ia mengatakan kepada Darsa hanya laki-laki yang berwewenang dalam rumah tangga dan perceraian adalah hak laki-laki (Berkisar Merah, 1993:76)”.

Pada kutipan di atas pengarang menjelaskan peristiwa yang dialami oleh tokoh Lasi yang mendapatkan perlakuan di tengah masyarakat. Pengarang menggambarkan 
bagaiman seorang Lasi di mata masyarakat desa teersebut bahkan keluarganya sendiri tidak mendukungnya. Selain itu, secara tersirat pengarang menggambarkan betapa sulitnya menjadi seorang Lasi yang selalu salah di mata orang lain. Dari kutipan di atas terlihat bahwa perempuan tidak mempunyai wewenang dan tidak berhak mengeluarkan pendapat, lak-laki hanya menganggap perempuan sebagai makhluk yang lemah dan jauh di bawah laki-laki sehingga laki-laki sesenaknya saja bersikap apalagi di dalam perceraian karena beranggapan perempuan tidak berhak atas perceraian, dari hal tersebut terlihat terjadi ketidakadilan gender kepada perempuan karena dianggap seorang yang lemah dan yang berwenang dalam rumah tangga adalah laki-laki. Hal tersebut terlihat ketidakadilan yang dialami oleh tokoh perempuan, sehingga perempuan dimarginalkan dan tentu saja merugikan perempuan.

"Para pemuda desa beranggapan bahwa sesungguhnya lelaki kurang tertarik terhadap perempuan yang terlalu cerdas apalagi berpendidikan terlalu tinggi. Bagi lelaki, perempuan yang kurang berpendidikan dan miskin tidak jadi soal asal dia cantik dan bekulit putih (Berkisar Merah, 1993:144)”.

Dari kutipan di atas, pengarang menjelaskan kepada pembaca bahwa di dalam novel tersebut masyarakat tidak mementingkan pendidikan bagi seorang perempuan dan bahkan masyarakat beranggapan perempuan yang berpendidikan tidak menarik. Pengarang juga menggambarkan pendapat masyarakat di dalam novel tersebut tentang pandangan masyarakat yang lebih memilih perempuan yang cantik daripada perempuan yang berpendidikan. Di dalam kutipan tersebut perempuan menjadi sebuah wacana pemberi makna untuk mendominasi selera masyarakat yang membentuk opini tentang perempuan. Perempuan bukan hanya tereksploitasi secara fisik, tetapi juga pikiran untuk mewujudkan citra cantik di kalangan masyarakat. Perempuan selalu dinomorduakan karena msyarakat beranggapan lelaki yang berhak berpendidikan bukan perempuan, sehingga perempuan selalu dirugikan dan dimarginalkan.

\section{Posisi Objek}

Sang tokoh perempuan yang menjadi tokoh utama di dalam novel ini menjelaskan keberadaannya yang mendapatkan perlakukan yang tidak adil di dalam masyarakat, terjadinya ketidakadilan yang ia terima di dalam hidupnya dan sebagai objek penceritaan.

"Salah saya apa jika saya terlahir seperti ini? saya tidak minta kulit putih dan mata sipit. Saya tidak bisa memilih dari siapa saya terlahir (Berkisar Merah, 1993:14)”.

Konteks pada kutipan di atas terjadi ketika Lasi ingin diperkosa oleh para lelaki desa yang menyalahkan Lasi karena Lasi berkulit putih dan bermata sipit karena anak haram dari orang Jepang, sehingga para lelaki itu tergoda dengan kecantikan Lasi. Namun, Lasi mencoba menjelaskan kepada lelaki tersebut bahwa ia juga tidak bisa memilih seperti apa dan dari siapa ia terlahir. Melihat kutipan di atas, perempuan hanya dipandang sebelah mata karena selalu dianggap makhluk lemah dan selalu di bawah lakilaki sehingga bisa berperilaku seenaknya terhadap perempuan dan tidak ada rasa hormat kepada perempuan.

"Walaupun saya mendapatkan hasil yang tidak setimpal dengan Mus, tapi saya bersyukur apa yang telah saya dapatkan dengan kerja keras saya salama ini (Berkisar Merah, 1993:205)””. 
Kutipan di atas terjadi ketika para karyawan Pak Tir menerima upah dari hasil kerjanya. Namun, Lasi tidak mendapatkan upah yang sama dengan temannya sesama karyawan di sana. Alasan Pak Tir tidak membedakan upah antara Lasi dengan karyawan lainnya karena Lasi seorang perempuan, pekerjaan Lasi pasti lebih ringan disbanding karyawan lainnya. Mendengar hal tersebut Lasi tetap bersyukur atas apa yang diterimanya karena itu merupakan hasil dari jerih payahnya sendiri. Dari kutipan di atas terlihat tokoh Lasi mendapat perlakukan yang tidak adil dan selalu memandang perempuan selalu lemah dibandingkan laki-laki, perempuan tidak mendapatkan hak yang sama di dalam pekerjaan karena perempuan hanya dipandang sebelah mata.

"Selalu aku yang menyiapkan tungku dan kawah untuk mengolah nira, mencari kayu bakar, dan membuat sebuah ayakan bambu yang disiapkan untuk menyaring nira. Lalu tugasmu apa? (Bekisar Merah: 15)".

Kutipan di atas terjadi ketika Lasi berkeluh-kesah kepada suaminya tentang pekerjaan yang selalu ia lakukan setiap harinya, sedangkan suaminya tidak berbuat apaapa sehingga Lasi merasa semua pekerjaan dibebankan kepadanya. Kutipan tersebut terlihat bahwa perempuan selalu diperlakukan seenaknya saja, padah pekerjaan yang dilakukan oleh tokoh Lasi tersebut dilakukan oleh laki-laki dan tanggungjwab seorang laki-laki. Namun, hal tersbut berbeda dengan yang dialami oleh tokoh Lasi dalam novel tersebut, di mana Lasi selalu mendapat perlakukan yang tidak adil dan perempuan selalu dianggap lemah sehingga laki-laki berbuat semaunya terhadap perempuan.

\section{Posisi Pembaca}

Model analisis Sara Mills ini juga membahas mengenai posisi pembaca. Posisi ini bermaksud melihat bagaimana pembaca menempatkan dirinya dalam teks yang ditampilkan. Menurut Sara Mills, posisi pembaca haruslah menjadi sebuah perhitungan penting dalam suatu teks. Seringkali posisi pembaca ini diabaikan sehingga pembuat teks semata dari sisi penulis, sehingga pembaca hanyalah sebagai khalayak pasif yang tidak mempengaruhi teks yang dibuat.

Penempatan posisi pembaca ini berhubungan dengan penyapaan atau penyebutan kepada pembaca yang ditulis di dalam novel, sebagaimana penempatan posisi pembaca ini umumnya dihubungkan dalam teks. Ini, misalnya dihubungkan dengan pemakaian kata ganti "kamu, anda dan sebagainya" di mana pembaca di sini disapa atau disebut secara langsung oleh teks (Eriyanto, 2015:207). Sara Mills juga menjelaskan mengenai kepada siapakah teks cenderung ditujukan, mempengaruhi bagaimana pembaca memosisikan dirinya. Di samping itu, penempatan posisi pembaca juga bisa diidentifikasi melalui pembacaan dominan (dominant reading). Hal ini terlihat pada pernyataan sang pengarang berikut ini:

"Begitu banyak penderitaan yang dialami oleh Lasi, jika itu terjadi pada perempuan di luar sana pastilah tidak akan sesabar seperti Lasi”. (Berkisar Merah, 1993:75)”.

Dengan menggunakan kata "perempuan di luar sana" sebagai bentuk penyapaan secara langsung kepada khalayak, pengarang berusaha untuk berkomunikasi secara langsung kepada pembaca sebagai sasaran. Posisi pembaca dalam novel Berkisar Merah karya Ahmad Tohari ini adalah masyarakat yang telah mmebaca novel ini, salah satunya adalah peneliti sendiri. Pada novel Berkisar Merah karya Ahmad Tohari ini menampilkan seorang perempuan yang selalu mendapat perlakukuan yang tidak baik dari masyarakat 
sekitar karena ia anak haram, hasil pemerkosaan orang Jepang sehingga ia selalu dipandang hina oleh masyarakat sekitar.

"Mungkin laki-laki di luar sana tidak akan ada seperti Darsa yang rela memperistri seorang perempuan yang selalu dipandang sebelah mata oleh masyarakat" (Berkisar Merah, 1993: 37).

Kutipan di atas terjadi ketika Darsa menerima Lasi sebagai istrinya, padahal Lasi selalu dipandang sebelah mata oleh masyarakat. Pengarang berusaha berkomunikasi kepada pembaca sebagai sasaran dari kata "mungkin laki-laki di luar sana tidak akan ada seperti Darsa". Pengarang memposisikan pembaca sebagai Darsa yang rela menerima Lasi sebagai istrinya, selain itu posisi pembaca tentu saja orang yang telah membaca novel ini dengan memahami maksud dari tujuan sang pengarang.

\section{SIMPULAN}

Berdasarkan pemaparan di atas, maka dapat disimpullkan bahwa pendekatan analisis wacana kritis Sara Mills memfokuskan seperti apa perempuan dimunculkan dalam wacana. Selama ini perempuan selalu disingkirkan dan berada dalam keadaan yang tidak baik dan para perempuan itu tidak diberikan kesempatan untuk membela diri. Adapun hasil dan pembahasan mengenai analisis wacana kritis Sara Mills dalam novel Berkisar Merah karya Ahmad Tohari dilihat dari posisi subjek-objek dan posisi pembaca, maka ditemukan posisi subjek sebanyak 4 data, posisi objek terdapat 3 data, dan posisi pembaca terdapat 2 data.

\section{DAFTAR PUSTAKA}

Eriyanto. (2002). Analisis wacana: Pengantar analisis teks media. Yogyakarta: LKIS. Eriyanto. (2006). Analisis wacana: Pengantar analisis teks media. Yogyakarta: LKIS. Fairclough, N. (2003). Language and power. Malang: Boyan Publishing.

Fauzan, U. (2014). Analisis wacana kritis dari model Faiclough hingga Mills. Jurnal PENDIDIK, 6(1), 1-15.

Ghufron, S. (2015). Kesalahan berbahasa: Teori dan aplikasi. Yogyakarta: Ombak. Masitoh. (2020). Pendekatan dalam analisis wacana kritis. Jurnal Elsa, 18(1), 66-76.

Mills, S. (1992). Knowing your place: A marxist feminst stylistic analysis. Dalam Michael Toolan (ed.) Language, text, and copntext: Essays in stylistics. London and New York: Routladge.

Moleong, L. J. (2004). Metode Penelitian Kualitatif. Bandung: Reamaja Rosdakarya.

Renkema. (2004). Introduction to discourse studies. Amsterdam/Philadelphia: John Benjamins Publishing Company.

Sari, D. P. (2012). Komodifikasi perempuan dalam iklan (Analisis wacana kritis Sara Mills pada iklan Purbasari Lulur Mandi). Jurnal Literasi. 2(1): 32-40.

Uljannah, U. (2017). Gerakan perlawanan perempuan dalam novel Maryam karya Okky Madasari dengan pendekatan Sara Mills. Skripsi. Jakarta: Univwrsitas Islam Negeri Syarif Hidayatullah.

Viora, D. (2018). Gender dan feminisme dalam Surat Kabar Harian Pekanbaru Metro Espres (MX): Kajian analisis wacana kritis perspektif Sara Mills. Jurnal AKRAB JUARA, 3(1), 150-163. 